\title{
Measurement of Natural and Artificial Radioactivity in Soil at Some Selected Thanas around the TRIGA Mark-II Research Reactor at AERE, Savar, Dhaka
}

\author{
Shawpan Chandra Sarkar', Idris Ali ${ }^{2}$, Debasish Paul ${ }^{2}$, Mahbubur Rahman Bhuiyan ${ }^{3 *}$ \\ Sheikh Mohammad Azharul Islam ${ }^{1}$
}

${ }^{1}$ Department of Physics, Jahangirnagar University, Dhaka, Bangladesh; ${ }^{2}$ Health Physics \& Radioactive Waste Management Unit, Institute of Nuclear Science \& Technology (INST), Atomic Energy Research Establishment (AERE), Dhaka, Bangladesh; ${ }^{3}$ Department of Physics, Comilla University, Comilla, Bangladesh.

E-mail: *rahmanmahbubur@ymail.com

Received October $2^{\text {nd }}$, 2011; revised November $3^{\text {rd }}$, 2011; accepted December $4^{\text {th }}, 2011$.

\begin{abstract}
The activity concentration of natural and fallout radionuclides in the soil at some selected Thanas around the TRIGA Mark-II Research Reactor at Atomic Energy Research Establishment (AERE), Savar, Dhaka were measured by using a high purity germanium detector (HPGe). The study revealed that only natural radionuclides were present in the samples and no trace of any artificial radionuclide was found. The average activity concentration of ${ }^{238} U,{ }^{232} \mathrm{Th}$ and ${ }^{40} \mathrm{~K}$ were found to be $37.8 \pm 5.6 \mathrm{~Bq} \cdot \mathrm{kg}^{-1}$, $58.2 \pm 11.0 \mathrm{~Bq} \cdot \mathrm{kg}^{-1}$ and $790.8 \pm 153.4 \mathrm{~Bq} \cdot \mathrm{kg}^{-1}$ respectively. The radium equivalent activity $\left(R_{e q}\right)$, absorbed dose rate $(D)$, external radiation hazard index $\left(H_{e x}\right)$ and internal radiation hazard index $\left(H_{i n}\right)$ were also calculated to find out the probable radiological hazard of the natural radioactivity.
\end{abstract}

Keywords: Natural Radionuclide, Artificial Radionuclide, HPGe Detector, TRIGA Mark-II Research Reactor, Activity Concentration

\section{Introduction}

Radioactivity may be natural and artificial. Natural radioactivity occurs due to extraterrestrial sources as well as from radioactive elements in the earth's crust. Significant amount of artificial (man-made) radioactivity is emitted by nuclear power plant, industrial plant and research facilities. A large amount of radiation releases due to accident of nuclear reactor.

Most widely spread natural radionuclides are from the family of Uranium $\left({ }^{238} \mathrm{U}\right)$, Thorium $\left({ }^{232} \mathrm{Th}\right)$, Actinium $\left({ }^{235} \mathrm{Ac}\right)$ and Kalium $\left({ }^{40} \mathrm{~K}\right)$. Significant amount of manmade radionuclides ${ }^{137} \mathrm{Cs}$ and ${ }^{90} \mathrm{Sr}$ may also present in soil as a result of nuclear weapon testing in the atmosphere, accidents (such as the Chernobyl power plant accident) and the routine discharge of radionuclides from nuclear installations [1]. ${ }^{137} \mathrm{Cs}$ dominates among durable artificial gamma radiators. It takes 300 year for it to fragment completely. Due to that it migrates in various geospheres and biological links. The biggest part of ${ }^{137} \mathrm{Cs}$ is accumulated in the upper layer of the soil and forest floor [2].

The TRIGA Mark-II Research Reactor of AERE is located at Savar of Dhaka District is a light-water-cooled graphite reflected reactor designed for continuous operation at a steady-state power level of $3 \mathrm{MW}$. A significant amount of low-level of solid, liquid and gaseous radioactive wastes are being generated from operation and maintenance of 3 MW TRIGA Mark-II Research Reactor. Radiation may release from these waste. These radioactive substance precipitated on the earth surface are either lifted again by the wind or penetrate into the ground. The radioactive substances are absorbed by plant through their roots and finally reach human body [2].

The aim of this study is to detect the natural ${ }^{238} \mathrm{U}$, ${ }^{232} \mathrm{Th}$ and $\left.{ }^{40} \mathrm{~K}\right)$ and probable artificial radionuclide $\left({ }^{137} \mathrm{Cs}\right)$ and to determine their activity level in the soil at Some Selected Thanas around the TRIGA Mark-II Research Reactor at AERE, Savar, Dhaka. 


\section{Methods and Analysis}

\subsection{Sample Collections and Preparation}

Eighteen soil samples were collected from the four Thanas (Dhamrai, Ashulia, Savar and Singair) around the TRIGA Mark -II Research Reactor, AERE, Savar, Dhaka. Each sample was collected maintaining a distance of about $1 \mathrm{~km}$ to $5 \mathrm{~km}$ from each other. The soil samples were collected at the depth of $5 \mathrm{~cm}$ with respect to the surface. About $1 \mathrm{~kg}$ of sample was collected from each location and each of the samples was placed in plastic packet and transported to the laboratory. All the samples were collected during the period of 25 October to 16 December in 2008. Each sample was segregated for stone and grass and then dried at about $110^{\circ} \mathrm{C}$ in an oven for 24 hours. The samples were then ground into fine powder with a grinder and collected after passing through a 10mesh screen. Thus, homogenized sample was transferred to sealable cylindrical plastic container of $7 \mathrm{~cm}$ height and $5.5 \mathrm{~cm}$ in diameter, marked individually with identification parameters. The net weights of all the samples were noted. All the sample containers were then sealed tightly with cap and wrapped with Teflon and thick vinyl tapes around their screw necks and finally air tightened with polythene pack and stored for minimum four weeks prior to counting, allowing establishment of secular equilibrium between the long lived ${ }^{238} \mathrm{U},{ }^{232} \mathrm{Th}$ and their decay products. Figures 1, 2 and $\mathbf{3}$ show the sampling loca-

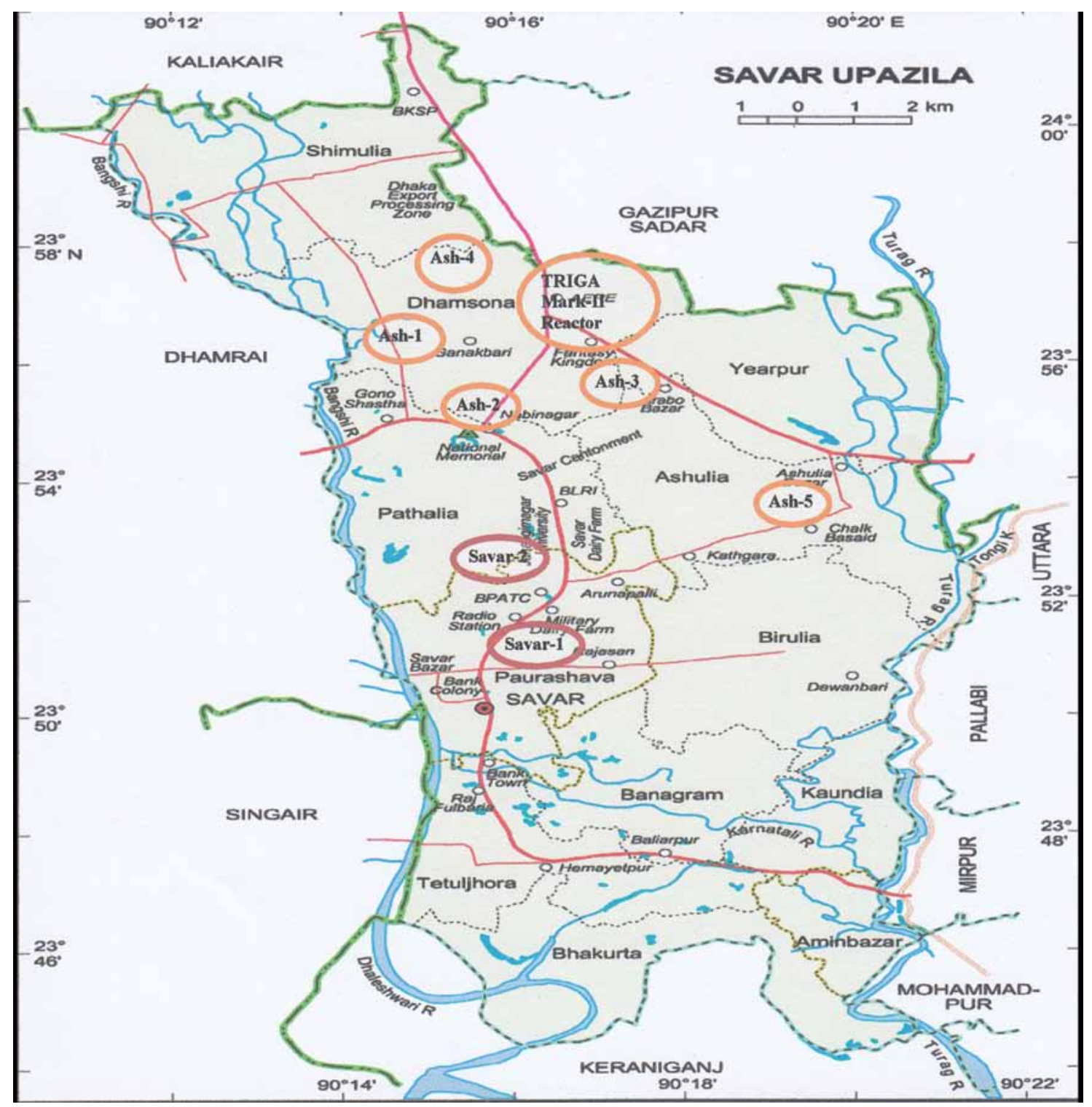

Figure 1. Map showing the different locations of sample collection in Savar and Ashulia Thana. 


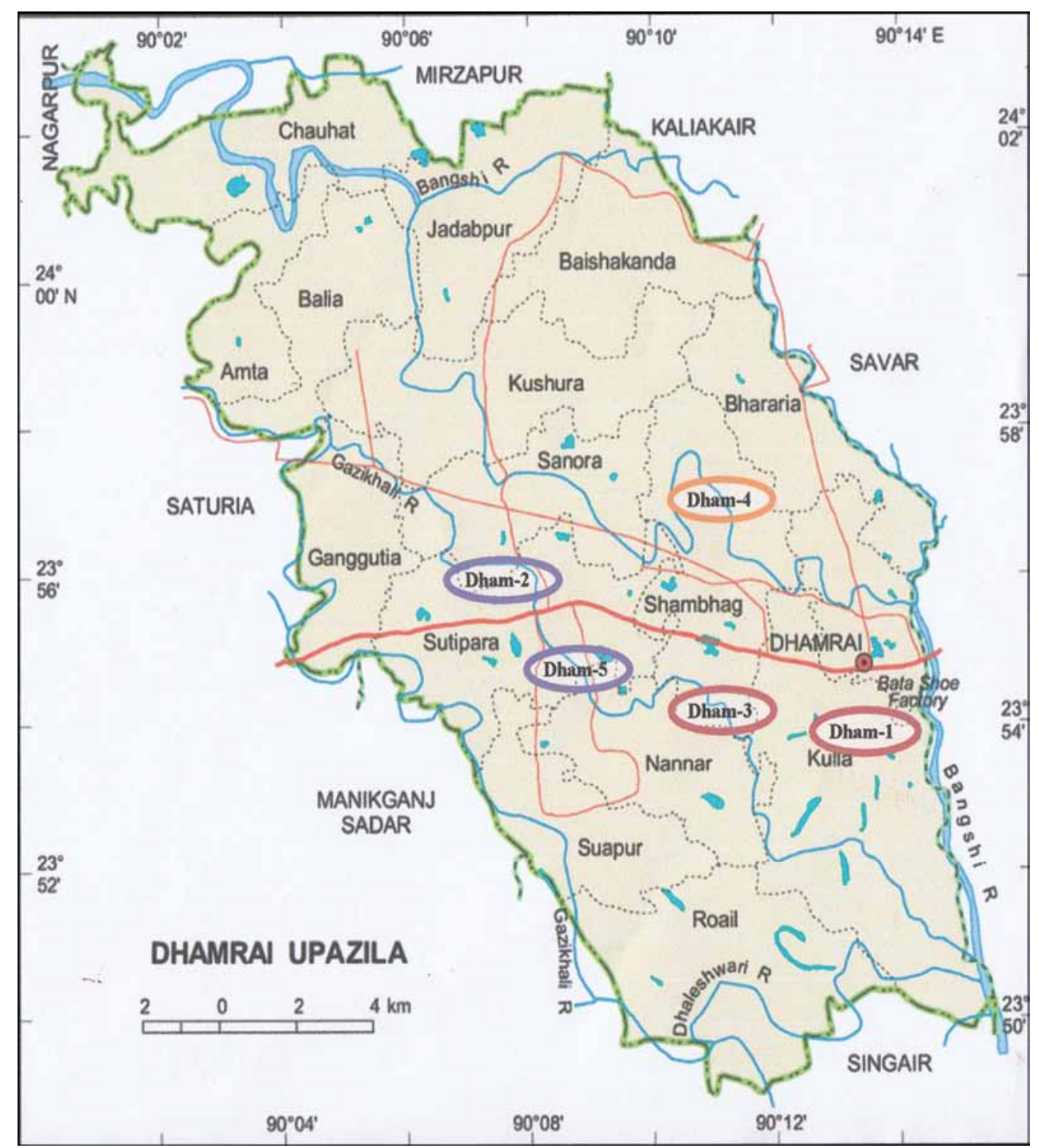

Figure 2. Map showing the different locations of sample collection in Dhamrai Thana.

tions.

\subsection{Data Collection and Analysis}

Each of the prepared samples and standard $\left(\mathrm{Al}_{2} \mathrm{O}_{3}\right.$ based ${ }^{226} \mathrm{Ra}$ ) were placed on the top of the HPGe detector within the shielding arrangement and counted for 10,000 seconds. The software of the HPGe detecting system provides the corresponding gamma spectra collected for both samples and standards. Gamma ray spectrometry can be used to identify gamma ray energies and consequently the radioactive species which are producing them. The area under the peak in a gamma ray spectrum represents the number of counts collected for only that gamma ray energy. These peak areas were used for determination of radioactivity concentration of the radionuclides present in the sample. The net count of the sample is obtained by subtracting a linear background distribution of the pulse height spectra from the corresponding peak energy area. From the net counts of the samples activity concentration of the radionuclides were calculated using the formula

$$
\mathrm{A}=\frac{\mathrm{CPS} \times 1000}{\varepsilon(\mathrm{abs}) \times \mathrm{I}_{\mathrm{r}}(\mathrm{abs}) \times \mathrm{W}}
$$

where, $\mathrm{A}$ is the activity concentration in $\mathrm{Bq} \cdot \mathrm{kg}^{-1}$, CPS is the net peak counts per second of the samples, $\mathrm{W}$ is the weight of the sample in gm, $\varepsilon(\mathrm{abs})$ is the absolute gamma peak detection efficiency, $I_{r}(a b s)$ is the absolute gam- 


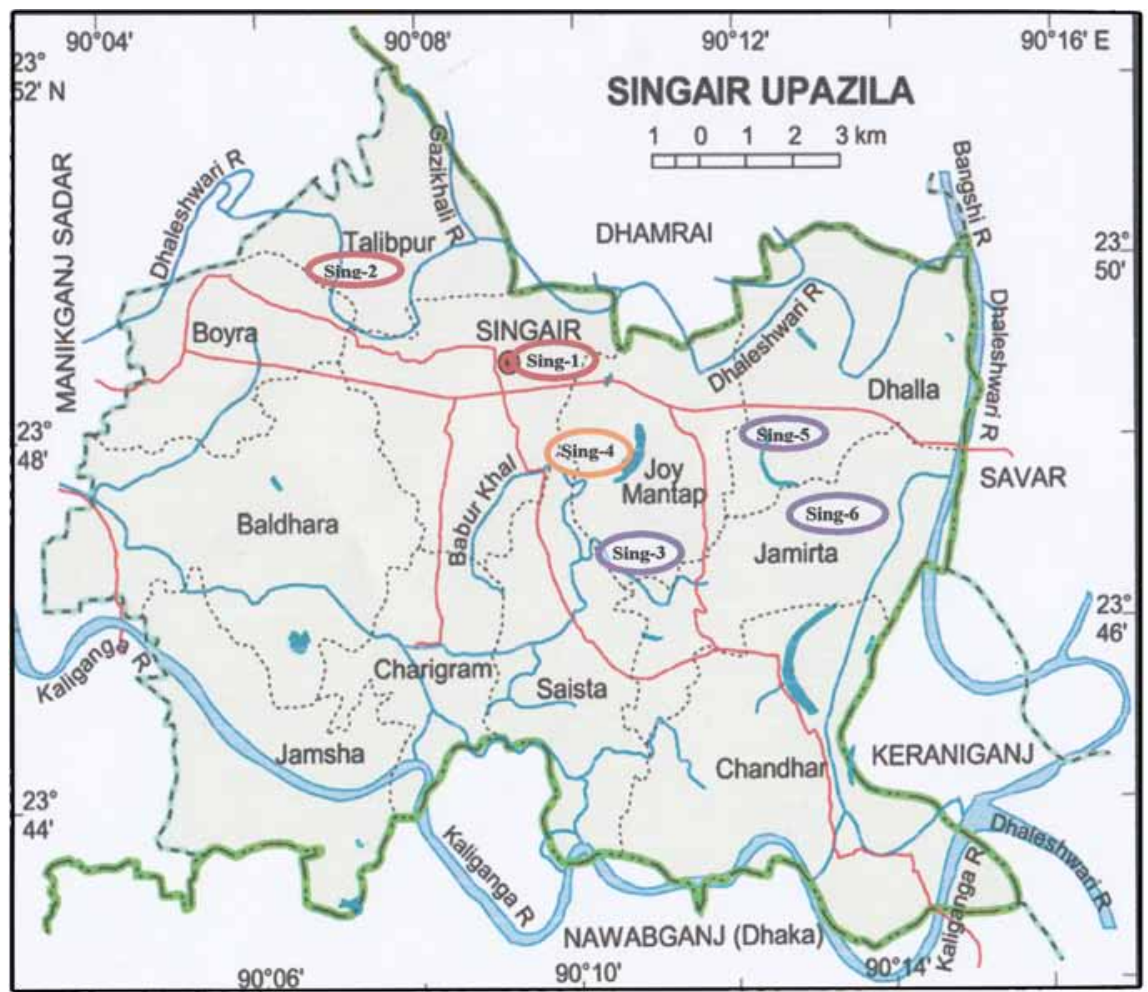

Figure 3. Map showing the different locations of sample collection in Singair Thana.

ma intensity of the corresponding gamma ray energy. Gamma rays intensities were taken from the literature [3]. The peak detection efficiencies were calculated from the full energy peak detection efficiency curve plotted using $\mathrm{Al}_{2} \mathrm{O}_{3}$ based ${ }^{226} \mathrm{Ra}$ standard as shown Figure 4. The error in the measurement have been expressed in terms of standard deviation $( \pm 2 \sigma)$, where $\sigma$ is expressed as,

$$
\sigma=\left[\frac{\mathrm{N}_{\mathrm{s}}}{\mathrm{T}_{\mathrm{s}}^{2}}+\frac{\mathrm{N}_{\mathrm{b}}}{\mathrm{T}_{\mathrm{b}}^{2}}\right]^{1 / 2}
$$

where $\mathrm{N}_{\mathrm{s}}$ is the counts measured in time $\mathrm{T}_{\mathrm{s}}$ and $\mathrm{N}_{\mathrm{b}}$ is the background counts measured in time $\mathrm{T}_{\mathrm{b}}$. The standard deviation $\pm 2 \sigma$ in CPS was converted into activity concentration in $\mathrm{Bq} \cdot \mathrm{kg}^{-1}$ according to Equation (1).

To determine the activity concentration, the $\gamma$-ray line

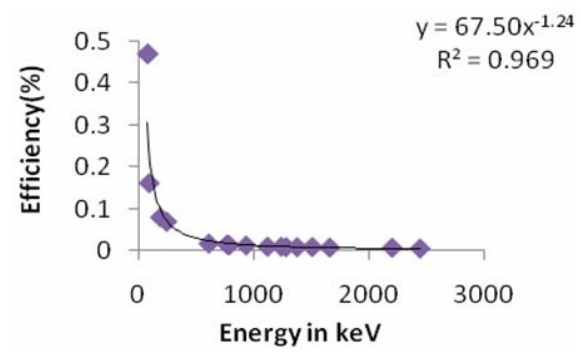

Figure 4. Efficiency curve of HPGe detector. of $351.92 \mathrm{keV}\left({ }^{214} \mathrm{~Pb}\right)$ and $609.31 \mathrm{keV}\left({ }^{214} \mathrm{Bi}\right)$ were used to determine ${ }^{238} \mathrm{U}$. The $\gamma$-ray line of $911.07 \mathrm{keV}\left({ }^{228} \mathrm{Ac}\right)$ and $583.19 \mathrm{keV}\left({ }^{208} \mathrm{Tl}\right)$ were used to determine ${ }^{232} \mathrm{Th}$. The $\gamma$-ray line of $1460.75 \mathrm{keV}$ was used to determine ${ }^{40} \mathrm{~K}$ and $661.31 \mathrm{keV}$ were used to determine ${ }^{137} \mathrm{Cs}$.

The radium equivalent activity $\left(\mathrm{R}_{\mathrm{eq}}\right)$ in $\mathrm{Bq} \cdot \mathrm{kg}^{-1}$ was calculated to compare the specific activity of the material containing different amount ${ }^{238} \mathrm{U},{ }^{232} \mathrm{Th}$ and ${ }^{40} \mathrm{~K}$ using the following relation given in [4]:

$$
\mathrm{Ra}_{\mathrm{eq}}=\left[\mathrm{C}_{\mathrm{Ra}}+1.43 \mathrm{C}_{\mathrm{Th}}+0.07 \mathrm{C}_{\mathrm{k}}\right] \mathrm{Bq} \cdot \mathrm{kg}^{-1}
$$

where $\mathrm{C}_{\mathrm{Ra}}, \mathrm{C}_{\mathrm{Th}}$ and $\mathrm{C}_{\mathrm{K}}$ are the activity concentration of ${ }^{238} \mathrm{U},{ }^{232} \mathrm{Th}$ and ${ }^{40} \mathrm{~K}$ respectively.

The $\gamma$-ray absorbed dose rate (D) in $\mathrm{nGyh}^{-1}$ in air due to the natural radionuclides ${ }^{238} \mathrm{U},{ }^{232} \mathrm{Th}$ and ${ }^{40} \mathrm{~K}$ was calculated using the formula as reported in [1]:

$$
\mathrm{D}=\left[0.42 \mathrm{C}_{\mathrm{Ra}}+0.662 \mathrm{C}_{\mathrm{Th}}+0.0432 \mathrm{C}_{\mathrm{K}}\right]
$$

where $\mathrm{C}_{\mathrm{Ra}}, \mathrm{C}_{\mathrm{Th}}$ and $\mathrm{C}_{\mathrm{K}}$ have the same meaning as Equation (3).

The soil is used for making earthen huts and bricks have the external radiation hazard index $\left(\mathrm{H}_{\mathrm{ex}}\right)$ and internal radiation hazard index $\left(\mathrm{H}_{\mathrm{in}}\right)$. The $\mathrm{H}_{\mathrm{ex}}$ and $\mathrm{H}_{\mathrm{in}}$ were calculated using the formula as given in [1].

$$
\mathrm{H}_{\mathrm{ex}}=\frac{\mathrm{C}_{\mathrm{Ra}}}{370}+\frac{C_{T h}}{259}+\frac{\mathrm{C}_{\mathrm{K}}}{4810} \leq 1
$$




$$
\mathrm{H}_{\text {in }}=\frac{\mathrm{C}_{\mathrm{Ra}}}{185}+\frac{\mathrm{C}_{\mathrm{Th}}}{259}+\frac{\mathrm{C}_{\mathrm{K}}}{4810}
$$

where $\mathrm{C}_{\mathrm{Ra}}$, $\mathrm{C}_{\mathrm{Th}}$ and $\mathrm{C}_{\mathrm{K}}$ have the same meaning as Equation (3).

\section{Results and Discussion}

The mean activity concentrations of ${ }^{238} \mathrm{U},{ }^{232} \mathrm{Th}$ and ${ }^{40} \mathrm{~K}$ were measured by using a HPGe detector. The activity concentration of ${ }^{238} \mathrm{U}$ ranged from $25.5 \pm 5.4$ to $64.4 \pm 6$ with an average value of $37.8 \pm 5.6 \mathrm{~Bq} \cdot \mathrm{kg}^{-1}$. The activity concentration of ${ }^{232} \mathrm{Th}$ ranged from $40.8 \pm 10.1$ to $77.4 \pm$ 11.2 with an average value of $58.2 \pm 11.0 \mathrm{~Bq} \cdot \mathrm{kg}^{-1}$. The activity concentration of ${ }^{40} \mathrm{~K}$ ranged from $425.1 \pm 156.1$ to $974.8 \pm 156.4$ with an average value of $790.8 \pm 153.4$ $\mathrm{Bq} \cdot \mathrm{kg}^{-1}$. Mean activity concentrations of ${ }^{238} \mathrm{U},{ }^{232} \mathrm{Th}$ and ${ }^{40} \mathrm{~K}$, Radium equivalent activity $\left(\mathrm{R}_{\mathrm{eq}}\right)$, dose rate $(\mathrm{D})$, external radiation hazard $\left(\mathrm{H}_{\mathrm{ex}}\right)$, internal radiation hazard $\left(\mathrm{H}_{\text {in }}\right)$ and range and mean values of activity concentration are shown in the Table $\mathbf{1}$ and Table 2, respectively. The mean activity concentrations of ${ }^{238} \mathrm{U},{ }^{232} \mathrm{Th}$ and ${ }^{40} \mathrm{~K}$ are shown graphically in the Figures 5-7, respectively.

The results of the present study showed that the activity concentration of thorium is 1.5 times higher than that of uranium. It is also observed that the activity concentration of ${ }^{40} \mathrm{~K}$ is 13.5 times higher than that of thorium and 20.9 times higher than that of uranium. The excessive usage of Potassium containing fertilizers (NPKS, MOP etc.) in the area adjacent to the sampling sites may contribute to the higher value of ${ }^{40} \mathrm{~K}$ activity [1].

A comparative study was also performed for the activity concentrations in the present work with the other studies performed in home and aboard and is shown in the Table 3.

The activity concentrations of the radionuclides in the soil samples of four Thanas around the TRIGA Mark-II research reactor in Bangladesh are within the range of values reported in the other work performed in home and abroad.

Since no ${ }^{137} \mathrm{Cs}$ radionuclide was detected in any of the soil samples, it indicates that there is no fission product

Table 1. Mean activity concentration of ${ }^{238} \mathrm{U},{ }^{232} \mathrm{Th},{ }^{40} \mathrm{~K}$ and ${ }^{137} \mathrm{Cs}$ in $\mathrm{Bq} \cdot \mathrm{kg}^{-1}$, the radium equivalent activity $\left(\mathrm{R}_{\mathrm{eq}}\right)$, absorbed dose rate (D), external hazard index $\left(\mathrm{H}_{\mathrm{ex}}\right)$ and internal hazard index $\left(\mathrm{H}_{\mathrm{in}}\right)$ in soil samples

\begin{tabular}{|c|c|c|c|c|c|c|c|c|}
\hline \multirow[b]{2}{*}{ Sam. ID } & \multicolumn{4}{|c|}{ Activity concentration in $\mathbf{B q} \cdot \mathbf{k g}^{-1}$} & \multirow[b]{2}{*}{$R_{e q}$ in $B q \cdot k^{-1}$} & \multirow[b]{2}{*}{ Dose rate in $\mathbf{n G y} \cdot \mathrm{h}^{-1}$} & \multirow[b]{2}{*}{$\mathbf{H}_{\mathrm{ex}}$} & \multirow[b]{2}{*}{$\mathbf{H}_{\text {in }}$} \\
\hline & ${ }^{238} \mathbf{U}$ & ${ }^{232} \mathrm{Th}$ & ${ }^{40} \mathbf{K}$ & ${ }^{137} \mathrm{Cs}$ & & & & \\
\hline \multicolumn{9}{|c|}{ Soil of Dhamrai Thana } \\
\hline Dham-1 & $64.4 \pm 6.0$ & $67.3 \pm 10.8$ & $974.8 \pm 156.4$ & ND & $228.8 \pm 32.3$ & $114 \pm 16.3$ & $0.62 \pm .08$ & $0.8 \pm 0.10$ \\
\hline Dham-2 & $40.4 \pm 5.8$ & $62.7 \pm 10.8$ & $950.6 \pm 157.5$ & ND & $196.5 \pm 32.2$ & $99.7 \pm 16.3$ & $0.54 \pm 0.08$ & $0.65 \pm 0.10$ \\
\hline Dham-3 & $48.9 \pm 5.7$ & $72.7 \pm 10.7$ & $934.6 \pm 153.9$ & ND & $218.2 \pm 31.7$ & $109.2 \pm 16$ & $0.47 \pm 0.08$ & $0.73 \pm 0.10$ \\
\hline Dham-4 & $40.4 \pm 5.2$ & $49.0 \pm 9.6$ & $880.0 \pm 143.0$ & ND & $172.0 \pm 28.9$ & $87.6 \pm 14.6$ & $0.48 \pm 0.08$ & $0.58 \pm 0.07$ \\
\hline Dham-5 & $38.8 \pm 5.9$ & $49.3 \pm 10.9$ & $863.5 \pm 162.2$ & ND & $169.6 \pm 32.7$ & $86.4 \pm 16.7$ & $0.47 \pm 0.09$ & $0.37 \pm 0.10$ \\
\hline \multicolumn{9}{|c|}{ Soil of Ashulia Thana } \\
\hline Ash-1 & $39.8 \pm 5.4$ & $68.5 \pm 10.4$ & $610.8 \pm 146.9$ & ND & $180.51 \pm 304$ & $88.5 \pm 15.4$ & $0.49 \pm 0.08$ & $0.6 \pm 0.09$ \\
\hline Ash-2 & $31.1 \pm 5.5$ & $60.8 \pm 10.7$ & $646.6 \pm 154.0$ & ND & $163.2 \pm 31.5$ & $81.3 \pm 15.9$ & $0.45 \pm 0.08$ & $0.53 \pm 0.1$ \\
\hline Ash-3 & $27.4 \pm 5.4$ & $58.0 \pm 9.9$ & $694.5 \pm 143.4$ & ND & $158.9 \pm 29.5$ & $79.9 \pm 14.9$ & $0.44 \pm 0.08$ & $0.51 \pm 0.09$ \\
\hline Ash-4 & $29.7 \pm 5.0$ & $47.5 \pm 18.5$ & $639.7 \pm 138.8$ & ND & $142.3 \pm 41.1$ & $71.6 \pm 20.2$ & $0.395 \pm 0.1$ & $0.47 \pm 0.12$ \\
\hline Ash-5 & $41.4 \pm 5.9$ & $66.7 \pm 11.2$ & $586.6 \pm 159.8$ & ND & $177.7 \pm 33$ & $87.0 \pm 16.8$ & $0.38 \pm 0.09$ & $0.59 \pm 0.1$ \\
\hline \multicolumn{9}{|c|}{ Soil of Savar Thana } \\
\hline Savar-1 & $45.3 \pm 5.7$ & $73.4 \pm 10.7$ & $579.4 \pm 151.1$ & ND & $190.7 \pm 31.5$ & $92.8 \pm 15.9$ & $0.52 \pm 0.08$ & $0.64 \pm 0.1$ \\
\hline Savar-2 & $39.3 \pm 5.8$ & $77.4 \pm 11.2$ & $425.1 \pm 156.1$ & ND & $179.6 \pm 32.7$ & $86.2 \pm 20.3$ & $0.49 \pm 0.09$ & $0.59 \pm 0.1$ \\
\hline \multicolumn{9}{|c|}{ Soil of Singair Thana } \\
\hline Sing-1 & $39.2 \pm 6.1$ & $57.6 \pm 11.5$ & $966.6 \pm 169.1$ & ND & $189.1 \pm 34.3$ & $96.5 \pm 17.5$ & $0.52 \pm 0.09$ & $0.63 \pm 0.11$ \\
\hline Sing-2 & $33.4 \pm 5.4$ & $41.9 \pm 10.0$ & $958.0 \pm 150.0$ & ND & $160.3 \pm 30.2$ & $83.2 \pm 15.3$ & $0.45 \pm 0.08$ & $0.53 \pm 0.09$ \\
\hline Sing-3 & $28.1 \pm 5.3$ & $41.0 \pm 10.0$ & $856.4 \pm 150.8$ & ND & $146.6 \pm 30.1$ & $75.9 \pm 15.3$ & $0.41 \pm 0.08$ & $0.48 \pm 0.09$ \\
\hline Sing-4 & $34.6 \pm 5.3$ & $53.0 \pm 10.0$ & $844.9 \pm 146.7$ & ND & $169.4 \pm 29.8$ & $86.1 \pm 15.1$ & $0.47 \pm 0.08$ & $0.56 \pm 0.09$ \\
\hline Sing-5 & $33.3 \pm 5.9$ & $61.3 \pm 11.5$ & $972.8 \pm 167.8$ & ND & $188.9 \pm 34$ & $96.7 \pm 17.3$ & $0.52 \pm 0.09$ & $0.61 \pm 0.10$ \\
\hline Sing-6 & $25.5 \pm 5.4$ & $40.8 \pm 10.1$ & $849.4 \pm 154.9$ & ND & $143.2 \pm 30.6$ & $74.4 \pm 15.6$ & $0.40 \pm 0.08$ & $0.47 \pm 0.09$ \\
\hline
\end{tabular}

ND: Not Detected. 


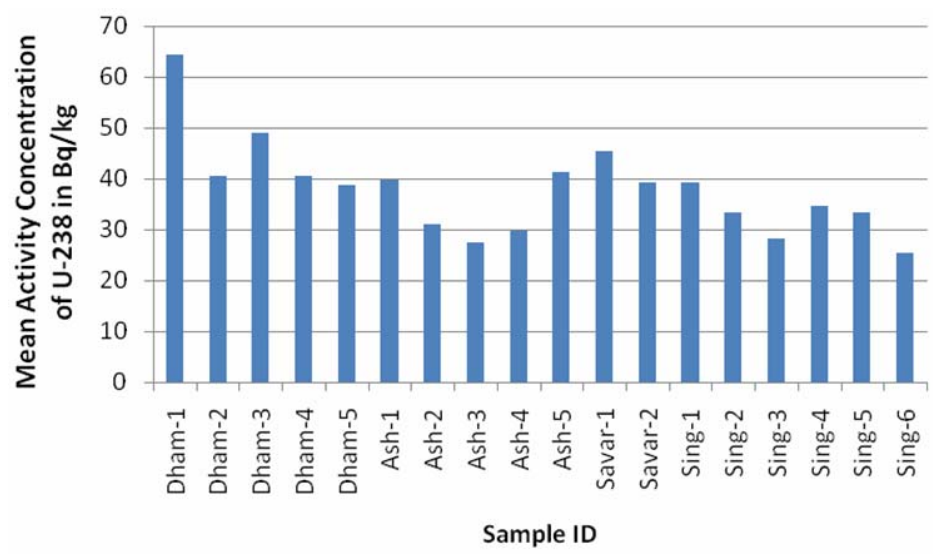

Figure 5. Mean activity concentration of ${ }^{238} \mathrm{U}$ in $\mathrm{Bq} \cdot \mathrm{kg}^{-1}$ in the collected soil samples.

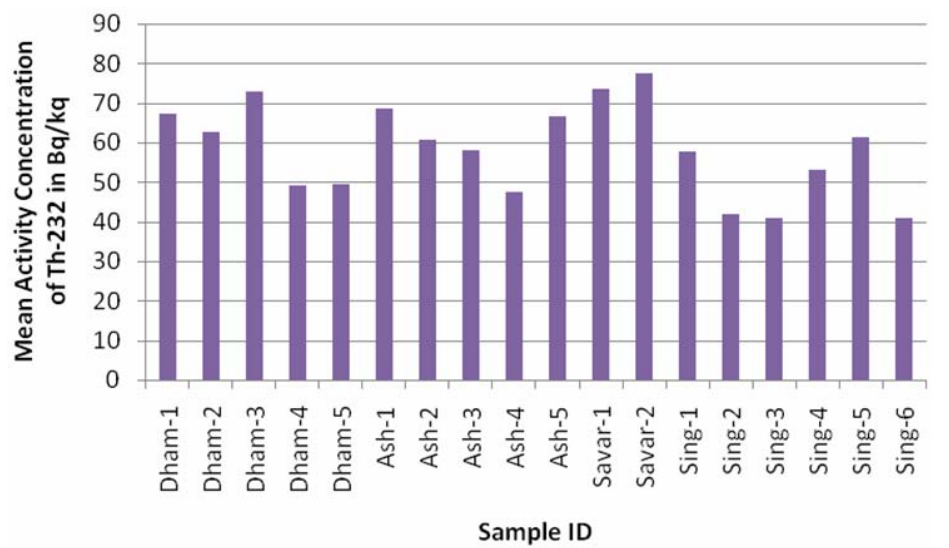

Figure 6. Mean activity concentration of ${ }^{232} \mathrm{Th}_{\text {in }} \mathrm{Bq} \cdot \mathrm{kg}^{-1}$ in the collected soil samples.

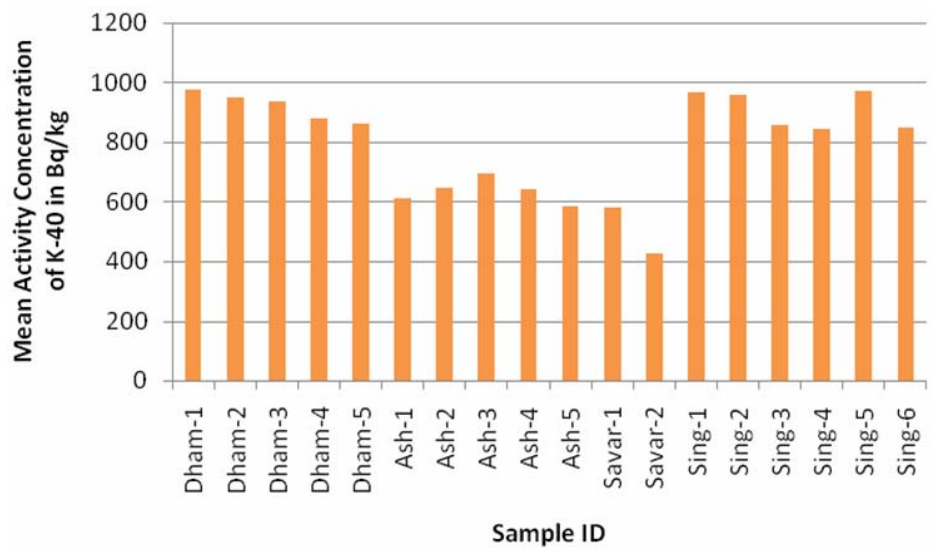

Figure 7. Mean activity concentration of ${ }^{40} \mathrm{~K}$ in $\mathrm{Bq} \cdot \mathrm{kg}^{-1}$ in the collected soil samples.

spread due to the operation of the TRIGA Mark-II research reactor or due to any other nuclear sources elsewhere.

\section{Conclusions}

The Savar region is one of the most populated regions in the country and socio-economic condition of this area is improving day by day due to industrial development. The country's only Research Reactor is established in this area. The use of the reactor and the accidental release of radionuclide may greatly modify the natural radiation environment. The activity concentrations of the radionu- 
Table 2. Range and mean value of activity concentrations of ${ }^{238} \mathrm{U},{ }^{232} \mathrm{Th},{ }^{40} \mathrm{~K}$ and ${ }^{137} \mathrm{Cs}$ in $\mathrm{Bq} \cdot \mathrm{kg}^{-1}$ of the samples.

\begin{tabular}{cccc}
\hline Radionuclide & Minimum & Maximum & Mean \\
\hline${ }^{238} \mathrm{U}$ & $25.5 \pm 5.4$ & $64.4 \pm 6$ & $37.8 \pm 5.6$ \\
${ }^{232} \mathrm{Th}$ & $40.8 \pm 10.1$ & $77.4 \pm 11.2$ & $58.2 \pm 11.0$ \\
${ }^{40} \mathrm{~K}$ & $425.1 \pm 156.1$ & $974.8 \pm 156.4$ & $790.8 \pm 153.4$ \\
${ }^{137} \mathrm{Cs}$ & $\mathrm{ND}$ & $\mathrm{ND}$ & $\mathrm{ND}$ \\
\hline
\end{tabular}

Table 3. Comparison of the present study with other work.

\begin{tabular}{ccccc}
\hline Location & ${ }^{226} \mathbf{R a}$ & ${ }^{232} \mathbf{T h}$ & ${ }^{40} \mathbf{K}$ & References \\
\hline Around TRIGA Mark-II (Bangladesh) & $\mathbf{3 7 . 8} \pm \mathbf{5 . 6}$ & $\mathbf{5 8 . 2} \pm \mathbf{1 1 . 0}$ & $\mathbf{7 9 0 . 8} \pm \mathbf{1 5 3 . 4}$ & Present Study \\
Louisiana (Soil), USA & $43-95$ & $50-190$ & $43-729$ & {$[5]$} \\
Irakia (sand), Greece & $212(24-765)$ & $43(18-66)$ & $1130(464-2464)$ & {$[6]$} \\
Nile Delta, Egypt & 17 & - & 316 & {$[7]$} \\
Jessore, Bangladesh & $48 \pm 9$ & $53 \pm 9$ & $481 \pm 78$ & {$[1]$} \\
Nigeria & $8.3 \pm 2.6$ & $34.3 \pm 3.4$ & $684 \pm 7.3$ & {$[8]$} \\
Chittagong, Bangladesh & 34.6 & 84 & 646 & {$[9]$} \\
Peshwar, Pakistan & 65 & & {$[10]$}
\end{tabular}

clides in the soil samples are in the range of the values reported in other countries, but the activity levels are slightly higher than the permissible activity levels which are in general 41.0, 52.2 and $230 \mathrm{~Bq} \cdot \mathrm{kg}^{-1}$ for ${ }^{238} \mathrm{U},{ }^{232} \mathrm{Th}$ and ${ }^{40} \mathrm{~K}$ respectively [11]. Further, the results of the present study would be useful as a base line data of the regions under study and also help as a guideline for the competent authority (Bangladesh Atomic Energy Commission) to go forward to fix up the dose limit for the radiation protection activities of the country and in the academic activities of the health physics, geophysics and environmental science.

\section{REFERENCES}

[1] K. A. Kabir, S. M. A. Islam and M. M. Rahman, "Distribution of Radionuclides in Surface Soil and Bottom Sediment in the District of Jessore, Bangladesh and Evaluation of Radiation Hazard," Journal of Bangladesh Academy of Science, Vol. 33, No. 1, 2009, pp. 117-130.

[2] D. Jasaitis, M. Peciuliene and A. Girgzdys, "Evaluation of Radionuclide Concentration in the Bottom Ground of Water Reservoir and Waterside Soil," Journal of Environmental Engineering and Landscape Management, Vol. 12, No. 3, 2004, pp. 85-90.

[3] International Atomic Energy Agency, "Measurement of Radionuclides in Food and Their Environment, A Guidebook,” No. 139-144, Vienna, 1989.

[4] M. R. Abdi, H. Faghihian, M. Kamali, M. Mostajaboddavati and A. Hasanzadeh "Distribution of Natural Radionuclides on Coasts of Bushehr, Persian Gulf, Iran,” Iranian Journal of Science \& Technology, Vol. 30, No. A3, 2006, pp. 259-269.
[5] R. D. Delaune, G. L. Jones and C. J. Smith. "Radinuclides Concentrations in Louisiana Soils and Sediments," Health Physics, Vol. 51, No. 2, 1986, pp. 239-244.

[6] G. Trabidou, H. Florou, A. Angelopoulos and Sakelliou, "Environmental Study of the Radioactivity of the Spas in the Island of Ikaria," Radiation Protection Dosimetry, Vol. 63, No. 1, 1996, pp. 63-67.

[7] N. M. Ibrahiem, A. H. Abdel Ghani, S. M. Ahawky, E. M. Ashraf and M. A. Faouk, "Measurement of Radioactivity Levels in Soils in the Nile Delta and Middle Egypt," Health Physics, Vol. 64, No. 6, 1993, pp. 620-627. doi:10.1097/00004032-199306000-00007

[8] M. A. Muhammad, I. F. Idris, P. M. Simon and S. A. Arabi, "Distribution of Gamma-Emitting Radionuclides in Soil around the Center for Energy Research and Training (CERT) Ahmadu Bello University, Zaria, Zaria-Nigeria,” Journal of American Science, Vol. 6, No. 12, 2010, pp. 995-1001.

[9] M. I. Chowdhury, M. N. Alam and S. K. S. Hazari, "Distribution of Radionuclides in the River Sediment and Costal Soil of Chittagong, Bangladesh and Evaluation of the Radiation Hazard," Applied Radiation and Isotope, Vol. 51, 1999, pp. 747-755. doi:10.1016/S0969-8043(99)00098-6

[10] S. Ali, M. Tufail, K. Jamie, A. Ahmed and H. A. Khan, "Gamma-Ray Activity and Dose Rate of Brick Samples from Some Area of North West Frontier Province (NWFP), Pakistan," Science of total Environment, Vol. 187, 1996, pp. 247-252. doi:10.1016/0048-9697(96)05109-1

[11] T. El-Zakla, H. A. Abdel-Ghny and A. M. Hassan, "Natural Radioactivity of Some Local Fertilizers," Romanian Journal of Physics, Vol. 52, No. 5-7, 2007, pp. 731739. 